\title{
THE GRASSLAND MESSAGE
}

A. R. RANKIN

Regional Advisory Officer, MAF, Invercargill

Abstract

With the Grassland Association now celebrating its 50th anniversary an attempt has been made to outline the main thrust of research and extension work and its effect on farming trends over ten year periods. The important grassland messages are covered and an attempt made to supply the grassland message for the future.

"Let us have a grassland caucus which will dominate grassland research and improvement." This was the plea of our first President, A. H. Cockayne, just fifty years ago.

The plea was accepted, but accepted more as a challenge than as a plea. The result has been not one grassland message but a whole series of messages as scientist, adviser and farmer have responded to this challenge. During this fifty years of productive gain this Association has provided opportunity for scientific workers to present their results under the critical eye of their peers and subject to the practical assessment of farmers. Advisers have sought each year at this conference new techniques and new thoughts on grasslands management. Farmers have presented their own thoughts and more importantly their tried and proven methods, as a very effective balance to scientific approach.

This conference has been a test arena and a sounding board, a place of vision and a place where hopes have crumbled, a place for debate, argument, praise and criticisms, but above all a place where the improvement of grassland has always been the ultimate goal.

From this "caucus" as described by Cockayne have come an endless stream of grassland messages.

THE 1930s

The decade from 1930 to 1940 saw the development of farm practices based on research into strains, topdressing and manage- 
ment, a situation probably no different from today except that the workers of the 1930s were pioneering these techniques. E. R. Hudson carried the message of subterranean clover on light land. The foundation was laid for the development of new pasture cul= tivars. Workers who had been active in the 1920s were now imbued with greater confidence and had gained in experience.

In his Presidential Address to the 1956 Conference, J. W. Calder mentions some of those who were expounding the grassland message, names such as A. W. Hudson, M. J. Scott, McCullough, McGillivray, Patterson, Tennant, Connell, Smallfield, Woodcock, Smith and Hamblyn.

This was the period that saw the establishment of the Grassland Research Station under the directorship of E. B. (later Sir Bruce) Levy. These were some of the people whose work provided the basis for the topdressing and management messages of the thirties - a period which also saw our bush sickness problem solved.

\section{THE 1940s}

Faced with war for the early 1940s the grassland message was one of economics, particularly with fertilizer and labour. In the second half of the decade land development boomed with the need to provide farms for soldier settlement. The work of Sears on grassland management, and Kelsey and Hoy with their work on grassland pest control, together with the arrival of improved grass strains, all played their part in grassland improvement. The advent of 'Grasslands Manawa', or $\mathrm{H} 1$ as it was then known, was perhaps the most significant of species improvement. For the southern areas of New Zealand, its introduction in the latter half of the 1940s assisted materially in shortening the winter feed gap.

In grassland research it is important not only to consider total dry matter production but also when that dry matter becomes available for the grazing animal. The advent of Manawa helped in the colder areas to close the winter gap, and, indeed, this breeding work of Corkill provided the first break-through in reducing winter reliance on supplementary feed crops.

\section{THE 1950s}

Pasture nutrition received a great deal of attention during the 1950s. Farmers now had a soil testing service available and names like Davies and Walker were adding their particular message to that of other workers of this period. 
Aerial topdressing really established itself during the 1950s and the promise it brought with oversowing and topdressing was one of real importance to the pastoral farmer. Up to 1950, 45400 ha had been topdressed by plane. In 1960, 1930000 ha were aerially topdressed in that year alone. There were, however, many new areas for investigation.

The plane made oversowing and' -topdressing possible but the question of the best species and seeding rates had to be answered. Optimum fertilizer rates and the type of fertilizer in terms of economic response also required investigation. Coating of seed, inoculation and the use of molybdenum were other areas for study. Application of the fertilizer and seed in terms of spread and density also required considerable research. One by one the problems were solved by the combined efforts of research workers, advisers and run-holders. This was very much a team effort with people like Harris, Suckling, Lobb, Cullen and Ludecke being among those who played a leading role.

\section{THE $1960 \mathrm{~s}$}

As we entered the 1960 s, improved subdivision, increased soil fertility through topdressing and stocking, more productive species, and sounder grazing management techniques developed in the 1950 s all added to our strengths.

This gave rise to a message which created more argument and debate than any other, a message which many called the "numbers game". There was, however, a potential to carry more stock than were being carried and so began the lift in stock numbers. In some cases this was overdone.. In many cases, while the farm property had the physical and productive ability to carry more stock, the rate of increase moved rather faster than the farmer's ability to improve his managerial skills and certainly faster than optimum to carry out the selection and culling necessary to maintain a reasonable level of per head performance in our livestock.

Stocking rates tended to drop back again because of this, to allow managerial skills and animal performance to improve, 'but nevertheless average stocking levels were higher than ever previously achieved. These were heady years when all the grassland messages of the previous thirty years found expression in higher stocking levels of Sheep, dairy cows and cattle.

an:

$$
\text { THE 1970s }
$$

The pace of the 1960s was not maintained in the 1970s. There was, as' mentioned, some reaction against higher stocking. The 
contrast between the $60 \mathrm{~s}$ and 70 s may also be explained by the implications of climate change. Salinger (1979), in a paper presented at a meteorological seminar recently, dubbed the period between 1950 and 1969 as the "Green Years" because this period was the most climatically favourable of any period during the past 20 years.

Conversely, the 1970s did not experience such co-operative climatic conditions. Despite this, in the colder areas of New Zealand where winter dormancy of pasture had twenty years before necessitated the growing of 8 ha of swedes per 1000 ewes, all-grass wintering became established. Improved fertility, improved pasture strains and improved management techniques enabled farmers to winter.on grass. Here, surely, is the practical application of the grassland message.

\section{THE 1980s}

We now stand on the threshold of the 1980s. Looking back over the years, it is obvious that in the technical sense there have been many grassland messages. What then is the grassland message? Lloyd George when Chancellor of the Exchequer in 1910 decided to tax whisky and in his wisdom decided to earmark the proceeds for agricultural research. Is this the grassland message we want?

At the present time there is a tendency in New Zealand for some diversification away from pastoral farming. Forestry, horticulture and arable farming are all expanding. Nevertheless, pastoral farming provides around $70 \%$ of New Zealand's export income and, despite the expansion of competitive enterprises, I see no major change in this situation. The major message which emerges from the last fifty years is that grassland farming has resilience, has the ability to adjust, and through the co-operative efforts of scientist, adviser and farmer will continue to expand, to reach new and higher levels of efficiency, and to remain the foundation of New Zealand's economy. The Grassland Association has in the past and will in the future play an important part in achieving this result.

Let us continue to have and to strengthen a grassland caucus which will dominate grassland research and improvements.

\section{REFERENCE}

Salinger, M. J., 1979. Symposium on the Value of Meteorology in Economic Pluming: N.Z. Met. Service: 63-78. 